\title{
HISTORY OF WOMEN IN THE UNITED STATES
}




\title{
HISTORY OF WOMEN IN THE UNITED STATES
}

Historical Articles on Women's Lives and Activities

\author{
Edited by Nancy F. Cott \\ Series ISBN 3-598-41454-4
}

1. Theory and Method in Women's History

ISBN 3-598-41455-2 Par 1

ISBN 3-598-41477-3 Part 2

2. Household Constitution and

Family Relationships

ISBN 3-598-41456-0

3. Domestic Relations and Law ISBN 3-598-41457-9

4. Domestic Ideology and Domestic Work ISBN 3-598-41458-7 Part 1 ISBN 3-598-41475-7 Part 2

5. The Intersection of Work and Family Life ISBN 3-598-41459-5 Part 1 ISBN 3-598-41476-5 Part 2

6. Working on the Land ISBN 3-598-41460-9

7. Industrial Wage Work ISBN 3-598-41461-7 Part 1 ISBN 3-598-41693-8 Part 2

8. Professional and White-Collar Employments ISBN 3-598-41462-5 Part 1 ISBN 3-598-4 1694-6 Part 2

9. Prostitution ISBN 3-598-41463-3
11. Women's Bodies: Health and Childbirth ISBN 3-598-41465-X

12. Education ISBN 3-598-41466-8

13. Religion ISBN 3-598-41467-6

14. Intercultural and Interracial Relations ISBN 3-598-41468-4

15. Women and War ISBN 3-598-41469-2

16. Women Together: Organizational Life ISBN 3-598-4 1470-6

17. Social and Moral Reform ISBN 3-598-41471-4 Part 1 ISBN 3-598-41695-4 Part 2

18. Women and Politics ISBN 3-598-41472-2 Part 1 ISBN 3-598-41697-0 Part 2

19. Woman Suffrage ISBN 3-598-4 1473-0 Part 1 ISBN 3-598-41696-2 Part 2

20. Feminist Struggles for Sex Equality ISBN 3-598-41474-9

10. Sexuality and Sexual Behavior ISBN 3-598-41464-1 


\section{HISTORY OF WOMEN IN THE UNITED STATES}

Historical Articles on Women's Lives and Activities

Industrial Wage

Work

PART 2

Edited with an Introduction by

Nancy F. Cott

Yale University

$\mathrm{K} \cdot \mathrm{G} \cdot$ Saur

Munich - New Providence $\cdot$ London - Paris · 1993 


\section{Publisher's Note}

The articles and chapters which comprise this collection originally appeared in a wide variety of publications and are reproduced here in facsimile from the highest quality offprints and photocopies available. The reader will notice some occasional marginal shading and text-curl common to photocopying from tightly bound volumes. Every attempt has been made to either correct or minimize this effect.

Copyright information for articles reproduced in this collection appears at the end of this volume.

\section{Library of Congreas Cataloging-In-Publication Data}

History of women in the United States : historical articles on

women's lives and activities / edited with

an introduction by Nancy F. Cort.

p. $\mathrm{cm}$.

Includes bibliographical references and indexes.

Contents: 1 . Theory and method in women's history -- 2. Household constitution and family relationships - 3. Domestic relations and law -- 4. Domestic ideology and domestic work -- 5. The intersection of work and family life -- 6. Working on the land .- 7. Industrial wage work -- 8. Professional and white-collar employments -9. Prostitution -- 10. Sexuality and sexual behavior -- 11. Women's bodies -- 12. Education -- 13. Religion -- 14. Intercultural and interracial relations -- 15. Women and war -- 16. Women together -- 17. Social and moral reform -- 18. Women and politics -19. Woman suffrage -- 20. Feminist struggles for sex equality.

ISBN 3-598-41454-4 (set)

1. Women--United States-History. 2. Women-United States-Social conditions. I. Coth, Nancy F. HQ1410.HS7 1992

305.4'0973--dc20

Die Deutsche Bibliothek - CIP - Einheitsaufnahme

History of Women in the United States: historical articles on women's lives and activities / ed. with an introd. by Nancy F. Cott.

- Munich ; London; New York ; Paris : Saur.

ISBN 3-598-41454-4

NE: Cot, Nancy F. (Hrsg.)

Vol. 7. industrial wage work

PL. 2. - (1993)

ISBN 3-598-41693-8

(1)

Printed on acid-free paper/Gedruckt auf sāurefreiem Papier

All Rights Strictly Reserved/Alle Rechte vorbehalten

K.G. Saur Verlag GmbH \& Co. KG, Munich 1993

A Reed Reference Publishing Company

Printed in the United States of America

Printed/Bound by Edwards Brothers Incorporated, Ann Arbor

ISBN 3-598-41693-8 (vol. 7/part 2)

ISBN 3-598-41454-4 (series) 